\title{
Urinary Incontinence in Pregnant Women: Integrative Review
}

\author{
Eveliny Silva Martins ${ }^{1}$, Ana Karina Bezerra Pinheiro' ${ }^{1}$, Priscila de Souza Aquino1, \\ Mônica Oliveira Batista Oriá ${ }^{1}$, Régia Christina Moura Barbosa Castro ${ }^{1}$, \\ Diego Jorge Maia Lima', Karízia Vilanova Andrade1, Carla Suellen Pires de Sousa², \\ Sâmia Monteiro Holanda ${ }^{1}$ \\ ${ }^{1}$ Department of Nursing, Federal University of Ceará, Fortaleza, Brazil \\ ${ }^{2}$ Department of Nursing, State University of Ceará, Fortaleza, Brazil \\ Email: *evelinymartins@yahoo.com.br
}

Received 21 February 2016; accepted 20 March 2016; published 24 March 2016

Copyright (C) 2016 by authors and Scientific Research Publishing Inc.

This work is licensed under the Creative Commons Attribution International License (CC BY). http://creativecommons.org/licenses/by/4.0/

\section{(c) (i) Open Access}

\begin{abstract}
Objective: To characterize the scientific production related to the impact of urinary incontinence on quality of life of pregnant women. Method: An integrative review carried out from September 2014 to May 2015. The search was conducted in six databases, and a final sample of seventeen publications was presented. The data were presented in tables. Results: Incontinence related factors are: Being older, second pregnancy, multiparity, constipation, smoking, and obesity. Stress incontinence is the most occurring in pregnant women, causing an adverse impact on quality of life. Discussion: It is for health professionals who try to create effective coping strategies for minimizing consequences generated by the accidental loss of urine. Conclusion: Urinary incontinence affects the mother's life, resulting in social, behavioral, physical and emotional harm, taking this woman to be excluded from society and feel insecure about their health.
\end{abstract}

\section{Keywords}

Urinary Incontinence, Quality of Life, Pregnant Women

\section{Introduction}

The Urinary Incontinence (UI) is currently defined by the International Continence Society (ICS) as the "complaint of any involuntary leakage of urine”. The characterization of the UI is classified as effort UI (EUI)simultaneous urinary loss to effort, exercise, coughing or sneezing; urgent UI-involuntary loss of urine accom-

${ }^{*}$ Corresponding author.

How to cite this paper: Martins, E.S., Pinheiro, A.K.B., Aquino, P.S., Oriá, M.O.B., Castro, R.C.M.B., Lima, D.J.M., Andrade, K.V., Sousa, C.S.P.de and Holanda, S.M. (2016) Urinary Incontinence in Pregnant Women: Integrative Review. Open Journal of Nursing, 6, 229-238. http://dx.doi.org/10.4236/ojn.2016.63023 
panied by or immediately preceded by sudden and uncontrollable urge to urinate, difficult to be delayed or mixed (MUI)-when there are signs and symptoms of both types reported above [1].

The incidence of UI is significantly higher in adults and appears two to four times more often in women than in men. The prevalence of urinary incontinence in women varies between $12 \%$ and $56 \%$ [2] [3]. Recent studies indicate that the UI is a high prevalence problem or worldwide public health disorder [4], which affects the quality of life (QOL) [5]. In Brazil, the studies related to the prevalence of UI and its risk factors are incipient, hindering to know the reliable dimension of the problem in our population [6]. Searches have estimated 200 million adults worldwide with UI [3].

It is worth noting that the QOF is a concept eminently human, which has been approximated to the degree of contentment found in family life, loving, social and environmental and existential aesthetic, encompassing many meanings, reflecting individuals and communities knowledge, experience and values [7].

Although UI is treated as relevant, it is still invisible to public policies, to forming organs and, consequently, clinical evaluation and intervention. This situation imposes a coping and difficulties experience on millions of people around the world, especially women [8].

The professional nurse has an essential role in assessing physical, emotional symptoms, and QOL of pregnant women, helping them with health promotion (HP), based in a skilled care and ensuring their well-being holistically. Although the incidence of UI increases with advancing age, the urine loss experience is a fact that not only occurs in older women but also among young and middle-aged women [6].

During pregnancy time, many changes at the pelvic floor functions occur. Besides the hormone effects modifications over the whole maternal organism, the local tissues, such as muscles, are also modified by them, which influence the accidental urine loss during pregnancy. It is emphasized that other changes deriving from the gestational cycle also act on the continence mechanism, such as the decrease of the function of the urethral length and of the maximum closure pressure, urethral bladder cervix increased mobility, lower intravaginal pressure [9], as well as the effect of progesterone which causes laxity of the bladder and ureter smooth muscles [10].

Under the obstetrics aspect, it is known that the presence of urinary symptoms interferes negatively on QOL during pregnancy, and these symptoms can intensify and worsen the overall health perception and impact of urinary incontinence during pregnancy [11].

Regarding the most frequent types of UI in women, EUI is the most common after childbirth, with a high commitment of QOL significantly affecting the aspects of physical and mental health, especially those with MUI [12]. Urinary symptoms related to obstetric factors are more frequent in SUI (58.3\%), and getting pregnant and giving birth are factors associated with urinary symptoms independent of the type of delivery, reaching various segments of the woman's life [13].

In some studies, comparing two groups of women (with or without urinary incontinence), it is observed: incontinent women became pregnant more often and had more deliveries than continent women, and there were more women with UI among those who had, at least, a normal birth [6].

From a more detailed assessment and recognition of the effects caused by the UI on the QOL of pregnant women, health professionals, especially nurses, can increase their actions promoting health, aimed at this profile of women as a way to lessen the discomfort generated by incontinence and mitigate its impact on the life of the mother. Therefore, this study aimed to characterize the scientific production related to UI effect on pregnant women's QOL.

\section{Methods}

\subsection{Type and Nature of the Research}

This is an integrative literature review following six distinct steps: 1) Identification of the theme and selection of the hypothesis or research question; 2) Establishment of inclusion and exclusion criteria of studies/sampling or literature search; 3) Definition of the information to be extracted from selected studies/categorization of studies; 4) Evaluation of the studies included in the integrative review; 5) Interpretation of results; 6) Presentation of review/knowledge synthesis [14].

\subsection{Research Environment}

The literature review includes articles indexed in the magazines portal of SCIELO (Scientific Electronic Li- 
brary), LILACS (Latin American Literature in Health Sciences), MEDLINE (Medical Literature Analysis and Retrieval System Online); CINAHL (Cumulative Index to Nursing \& Allied Health Literature); COCHRANE and SCOPUS.

\subsection{Data Collection}

The search was conducted in September 2014 to May 2015, guided by the following question: What are the factors related to UI and its consequences in the lives of pregnant women? Articles were eligible if published in journals indexed in the mentioned bases, through controlled Keywords: urinary incontinence; women; pregnant women. The urinary incontinence key word was chosen for showing a greater number of articles related to this study theme, when used at the data basis. This descriptor inclusion or replacement by other word didn't bring enough articles or any article that fulfilled the inclusion criteria.

Regarding the SciELO data basis, 452 with the incontinência urinária descriptor were found. When adding the mulheres descriptor, 128 articles were found. When refining the research, adding the gestantes descriptor, nine complete articles were found and only two of them were related to the theme.

At the LILACS data basis, 547 articles were found, using the incontinência urinária descriptor. When including the mulheres descriptor, 118 articles were found. When adding the third descriptor, gestantes, one complete article was found. At the MEDLINE data basis, 32.810 articles were found with the urinary incontinence descriptor. When conducting the urinary incontinence versus women cross-over, 3864 articles were found. When including the third descriptor, pregnant women, 31 articles were found. Among them, 21 articles were complete, five of them were related to the inclusion criteria, and one of them was repeated, totalizing four articles.

At the CINAHL data basis, when using the urinary incontinence descriptor, 6.773 published articles were found. Refining the research, including the women descriptor, the result was reduced to 758 ; when putting the pregnant women descriptor, eight articles were found, from which six were complete, but none of them attended the inclusion criteria. Regarding the SCOPUS data basis, 46.374 articles were found with the urinary incontinence descriptor. When adding the women descriptor, the research result decreased to 12.798, and, lastly, the pregnant women descriptor refined the research to 273 articles. Among them, 22 were related to the theme, from which 6 were incomplete and 6, repeated, totalizing 10 complete articles. At the COCHRANE data basis, 3.050 articles regarding the urinary incontinence descriptor were found, which shortened to 1.281 articles when adding the women descriptor. The research decreased to 23 articles when using the pregnant women descriptor; however only one article was related to the theme and none was fully available.

Inclusion criteria were: full research articles, be available electronically, published in Portuguese, English or Spanish, and with the presence of UI during pregnancy without restriction of the date of publication. Informal case reports, book chapters, reflection papers, dissertations, theses, reports, editorials not scientific journals and studies inability to access the publication were excluded. Table 1 shows a selection of items according to the databases.

Table 1. Selection of research articles on databases according to the established inclusion criteria. Fortaleza, May 2015.

\begin{tabular}{|c|c|c|c|c|c|c|c|}
\hline & Scielo & Lilacs & Medline & Cinahl & Scopus & Cochrane & Total \\
\hline Production found & 09 & 01 & 31 & 08 & 273 & 23 & 345 \\
\hline It does not address the topic & 05 & -- & 17 & 08 & 251 & 22 & 303 \\
\hline Not available in full & -- & -- & 10 & 02 & 06 & 23 & 39 \\
\hline Not having the inclusion criteria & 02 & -- & 17 & 08 & 257 & 23 & 305 \\
\hline Repeated & -- & -- & 01 & -- & 06 & -- & 07 \\
\hline TOTAL & 02 & 01 & 04 & -- & 10 & -- & 17 \\
\hline
\end{tabular}

Source: Elaborated by the authors. 


\section{Results}

The final sample consisted of 17 articles. For a better understanding of the included studies, Table 2 shows the detailing of the studies.

Analyzing the goals of the studies, they sought to identify the impact on QOL caused by UI; analyze the incidence and prevalence of incontinence; the features as type, symptoms, frequency; risk factors, severity, and impact on a routine of pregnant women.

Out of the 17 works found, six were originated in Brazil, and the other 11 studies were published in different places of the world such as the Netherlands, Mexico, Thailand, Spain, Norway, India, Ankara, Nigeria, USA. It is noticed that the topic is discussed as a common problem among countries. However, certain incipient is revealed about publications in Brazil. In Brazil, there are few scientific studies related to UI during pregnancy, complicating the identification of the affected population [15].

Only two publications were found in 2001, and most came from 2008. It is believed that research focusing on UI among pregnant women should take a growth curve, at the national and international level, because 13 of the found articles were published during the last five years.

It is emphasized that, at the time the studies evaluated the pregnant women, their pregnancy had from 2 up to 40 weeks. The gestational age knowledge, along with the related complaints, may influence the professional's provided care. Two articles studied women into postpartum period and three papers, in any period.

It is noteworthy that women, especially pregnant women with UI begin to experience a more reclusive and lonely experience, for failing to carry out social activities, leisure and spiritual, attending only places which have toilets, but also repressing needs and desires concerning sexuality, due to the insecurity and hence the fear of losing urine during sex. These situations cause them to urinate before intercourse or to evade any interpersonal relationship with the opposite sex [8].

It is important to consider aspects that drive the UI in pregnant context to understand their difficulties, anxieties, sorrows, physical and emotional, so they can meet their routine and seek to play collaborative actions relevant to this situation. In Table 3, the factors related to UI and its consequences in the lives of pregnant women are shown.

\section{Discussion}

The articles deal similar factors related to the UI during pregnancy. However, it is known that other factors such as social support and emotions can also have a negative effect on QOL during the pregnancy cycle, regardless of whether or not a urinary complaint [11]. Even though for pregnant women with urinary incontinence, the loss of urine do not seriously affect their life, but it affects their physical, mental and social domains of QOL, causing discomfort/anxiety [16]. Women with urinary symptoms feel a greater need for care and health information and are impacted in various areas of social, emotional, sexual activity, worsening of general health perception, and the sleep/disposal areas and limitations of daily activities that get the worst scores, and have little participation in leisure activities [11] negatively affecting their QOL [4] [17].

However, it is reflected in the magnitude of the impact of this disease, apparently discreet, affecting the most sensitive aspects of the routine of a woman, which faces the physical and social discomfort and fully changes in the context in which she lives. Pregnant women with UI show damage in QOL, affecting their ability to perform tasks outside the home, physical activity, leisure activity, the ability to travel, social, emotional state and frustration, especially in mixed UI [18] and increased social and hygienic discomfort [19]. In another study, most incontinent women (83.4\%) stated that it did not interfere with their routines, while for the other women, there was interference in varying degrees in daily routines [20].

More than half of the studies in this review [12] show the impact on QOL presented by pregnant women, revealing social, emotional, sexual and hygienic problems which reflect the emergence of distress and annoyance in the daily lives of these women who live in embarrassment situations and considerable anxiety levels. Factors related to UI, causing impacts in routine are the mother being older; be her second previous vaginal delivery [4] [11] [15] [17] [20]-[25], most of them having EUI, followed by MUI associated with urinary symptoms (urinary frequency and at night) [15]-[21], uterine weight affects the urination; laughter, movement increases intra-abdominal pressure [24]; multiparity; number of births; gestational age [4] [15] [22] [24] [27] [28]; increased pressure during coughing that causes decreased contraction of the pelvic muscles [29].

Some risk factors that contribute to the development of UI in pregnant women, such as obesity, due to the 
Table 2. Studies included in the bibliographic databases. Fortaleza, May 2015.

\begin{tabular}{|c|c|c|}
\hline Objectives of the study & Year & Place/sample/the gestational age \\
\hline $\begin{array}{l}\text { To compare the quality of life of pregnant women without urinary symptoms } \\
\text { to those with urinary symptoms, and identify factors that } \\
\text { can affect the quality of life during this phase of a woman's life. }\end{array}$ & 2014 & $\begin{array}{l}\text { Place: Recife/PE-Brazil. } \\
\text { Sample: } 40 \text { pregnant women } \\
24^{\mathrm{a}}-28^{\mathrm{a}} / 34^{\mathrm{a}}-36^{\mathrm{a}} \text { weeks }\end{array}$ \\
\hline $\begin{array}{l}\text { To validate two measure instruments, UDI-6 and IIQ-7, for the study } \\
\text { of urinary incontinence and its impact on quality of life of pregnant women. }\end{array}$ & 2011 & $\begin{array}{l}\text { Place: Barcelona } \\
\text { Sample: } 181 \text { pregnant women } \\
34 \text { weeks (Median) }\end{array}$ \\
\hline $\begin{array}{l}\text { To assess the impact of pregnancy and childbirth in the onset of } \\
\text { SIU and EUI and its association with social and hygienic discomfort. }\end{array}$ & 2008 & $\begin{array}{l}\text { Place: Rio de Janeiro/RJ-Brazil } \\
\text { Sample: } 120 \text { pregnant women } \\
>26 \text { weeks }\end{array}$ \\
\hline $\begin{array}{l}\text { To explain the pathophysiology that leads SUI in pregnant women } \\
\text { and the prevalence and treatment of SUI during pregnancy. }\end{array}$ & 2013 & $\begin{array}{l}\text { Place: Thailand } \\
\text { Sample: } 28 \text { complete texts } \\
\text { - }\end{array}$ \\
\hline $\begin{array}{l}\text { To determine the prevalence of urinary incontinence in women } \\
\text { attending the National Institute of Perinatology Isidro Espinosa de los } \\
\text { Reyes and assess the type, severity and frequency of involuntary loss of urine. }\end{array}$ & 2011 & $\begin{array}{l}\text { Place : Mexico } \\
\text { Sample: } 620 \text { pregnant women } \\
\text { Among } 6 \text { and } 40 \text { weeks }\end{array}$ \\
\hline $\begin{array}{l}\text { To evaluate the prevalence and development of urinary incontinence in nulliparous } \\
\text { pregnant women, both subjectively and objectively, and investigate incontinence } \\
\text { relationship with mobility ureterovesical junction measured by perineal ultrasound. }\end{array}$ & 2001 & $\begin{array}{l}\text { Place: The Netherlands } \\
\text { Sample: } 144 \text { pregnant women } \\
\text { Among } 2 \text { and } 38 \text { weeks }\end{array}$ \\
\hline $\begin{array}{l}\text { To evaluate the prevalence and risk factors for } \\
\text { urinary incontinence in healthy pregnant women. }\end{array}$ & 2010 & $\begin{array}{l}\text { Place: São José do Rio Preto-Brazil } \\
\text { Sample: } 500 \text { pregnant women } \\
\text { Any week }\end{array}$ \\
\hline To identify risk factors for the development of the EUI in pregnant women. & 2014 & $\begin{array}{c}\text { Place: Thailand } \\
\text { Sample: } 13 \text { articles } \\
\text { - }\end{array}$ \\
\hline $\begin{array}{l}\text { To determine the prevalence of UI during pregnancy and if there } \\
\text { are differences between the characteristics of incontinence and } \\
\text { women affected during the first and third trimesters of pregnancy. }\end{array}$ & 2014 & $\begin{array}{l}\text { Place: Spain } \\
\text { Sample: } 224 \text { pregnant women } \\
\text { Until } 28 \text { semanas }\end{array}$ \\
\hline $\begin{array}{l}\text { To analyze the strength of the pelvic floor muscles (SOFM), } \\
\text { urinary continence and quality of life associated with urinary } \\
\text { incontinence (UI) in women in the first trimester of pregnancy. }\end{array}$ & 2014 & $\begin{array}{l}\text { Place: Guarulhos/SP-Brazil } \\
\text { Sample: } 500 \text { pregnant women } \\
<13 \text { weeks }\end{array}$ \\
\hline $\begin{array}{l}\text { To investigate the occurrence of urinary incontinence (UI) in pregnant women, } \\
\text { and the relationship with sociodemographic variables and quality of life. }\end{array}$ & 2013 & $\begin{array}{l}\text { Place: SP, PR, RS-Brasil } \\
\text { Sample: } 495 \text { pregnant women } \\
\text { Immediately post partum }\end{array}$ \\
\hline $\begin{array}{l}\text { To describe the prevalence of urinary incontinence (UI) in the third trimester } \\
\text { and determine which variables are associated with UI in this period. }\end{array}$ & 2013 & $\begin{array}{l}\text { Place: Florianópolis-Brazil } \\
\text { Sample: } 242 \text { pregnant women } \\
\text { Near to giving birth }\end{array}$ \\
\hline $\begin{array}{l}\text { To investigate the prevalence of urinary incontinence (UI) in a multi-ethnic } \\
\text { population of pregnant women and analyze possible } \\
\text { associations of known risk factors for UI in such a population. }\end{array}$ & 2012 & $\begin{array}{l}\text { Place: Norway } \\
\text { Sample: } 722 \text { pregnant women. } \\
28 \text { weeks }\end{array}$ \\
\hline $\begin{array}{l}\text { To identify and investigate the prevalence of UI during pregnancy } \\
\text { and the related risk factors and to assess its impact on quality of life. }\end{array}$ & 2010 & $\begin{array}{c}\text { Place: Ankara } \\
\text { Sample: } 393 \text { pregnant women }\end{array}$ \\
\hline $\begin{array}{l}\text { To determine the prevalence and severity of urinary } \\
\text { incontinence during pregnancy in Zaria, Nigeria. }\end{array}$ & 2010 & $\begin{array}{l}\text { Place: Nigeria } \\
\text { Sample: } 204 \text { pregnant women } \\
\text { Any week }\end{array}$ \\
\hline $\begin{array}{l}\text { To discover the prevalence of various urological symptoms in pregnant women, } \\
\text { the status before pregnancy and their perception of impact. }\end{array}$ & 2009 & $\begin{array}{l}\text { Place: India } \\
\text { Sample: } 240 \text { pregnant women } \\
\text { Any week }\end{array}$ \\
\hline $\begin{array}{l}\text { To describe the incidence of urinary incontinence (UI) during pregnancy } \\
\text { and the postpartum period and to identify potential contributing factors. }\end{array}$ & 2001 & $\begin{array}{c}\text { Place: USA } \\
\text { Sample: } 50 \text { pregnant women } \\
\text { Post partum }\end{array}$ \\
\hline
\end{tabular}

Source: Elaborate by the authors. 
Table 3. Distribution of factors related to UI and its consequences in the lives of pregnant women. Fortaleza, May 2015

\begin{tabular}{|c|c|c|}
\hline $1^{\circ}$ author & Related factors & Consequences \\
\hline Moccellin A.S. & $\begin{array}{l}\text { More common in previous vaginal birth } \\
\text { second childbirth older. }\end{array}$ & $\begin{array}{l}\text { Impairment in personal, social support, relationships, } \\
\text { and sexual activity. Little leisure activity, social awkwardness, } \\
\text { poor physical security, emotional and negative impact on QOL, } \\
\text { worsening of general health perception, decreased sleep. }\end{array}$ \\
\hline $\begin{array}{l}\text { Hernandez } \\
\text { R.V.R. }\end{array}$ & $\begin{array}{l}\text { Pregnant women had } \\
\text { lost daily/continuous urine. }\end{array}$ & $\begin{array}{l}\text { Negative impact on QOL affecting the ability to perform the tasks } \\
\text { away from home, physical activity, leisure, travel ability, social, } \\
\text { emotional state and frustration, especially in mixed UI. }\end{array}$ \\
\hline Scarpa K.P. & $\begin{array}{l}\text { The instability and pain in the pelvic-lumbar } \\
\text { segment, associated with a decrease in voluntary } \\
\text { control of the striated muscles of the pelvic floor. }\end{array}$ & $\begin{array}{l}\text { Increased feeling of social and hygienic discomfort } \\
\text { and impairment of daily activities. }\end{array}$ \\
\hline Sangsawang B. & $\begin{array}{l}\text { Increase the mounting pressure of the uterus and } \\
\text { fetal weight and hormone related to pregnancy. }\end{array}$ & More EUI development. \\
\hline Górbea C.V. & Multiparity and gestational age. & $\begin{array}{l}\text { Involvement is increasing in the second } \\
\text { trimester of pregnancy. }\end{array}$ \\
\hline Wijma J. & $\begin{array}{l}\text { Increased pressure during coughing. } \\
\text { The degree of incontinence } \\
\text { worsens as the pregnancy progresses. }\end{array}$ & $\begin{array}{l}\text { Increased UI on } 16 \% \text { in pregnant women with } 12 \text { - } 16 \text { weeks, } \\
30 \% \text { at } 28 \text { - } 30 \text { weeks and } 35 \% \text { at } 36 \text { - } 38 \text { weeks of gestation. }\end{array}$ \\
\hline Martins G. & $\begin{array}{l}\text { Multiparity, lifestyle, obesity, smoking, c } \\
\text { onstipation, daily coffee consumption, employment. }\end{array}$ & $\begin{array}{l}\text { Urgency urinary, at night, bed-wetting, } \\
\text { and feeling of incomplete emptying of the bladder. }\end{array}$ \\
\hline Sangsawang B. & $\begin{array}{l}\text { Age, obesity, smoking, constipation, EUI } \\
\text { pre-pregnancy, gestational } \\
\text { diabetes mellitus, obesity, BMI. }\end{array}$ & Development of EUI. \\
\hline Martínez F. & BMI and third gestational trimester. & $\begin{array}{l}\text { The UI does not seriously affect everyday life, } \\
\text { but affects physical, mental and social domains of QOL, } \\
\text { causing discomfort/anxiety. }\end{array}$ \\
\hline Riesco M.L.G. & $\begin{array}{l}\text { Older age, a greater number of pregnancies, } \\
\text { births and previous vaginal delivery } \\
\text { with perineal trauma in the previous delivery, } \\
\text { overweight and obesity, previous UI. }\end{array}$ & UI in the first trimester of pregnancy. \\
\hline Oliveira C. & $\begin{array}{l}\text { Multiparity, vaginal childbirth, overweight, } \\
\text { and obesity. More common in black women. }\end{array}$ & Negatively affect the QOL of women. \\
\hline Sacomori C. & $\begin{array}{l}\text { Age, a number of pregnancies, } \\
\text { marital status, constipation, } \\
\text { chronic bronchitis and depressive symptoms. }\end{array}$ & $\begin{array}{l}25.7 \% \text { of the women said that the UI did not interfere } \\
\text { in daily life, but } 41 \% \text { said were medium to very interfered. }\end{array}$ \\
\hline $\mathrm{Bø,} \mathrm{K.}$ & $\begin{array}{l}\text { Etnia, paridade e idade são } \\
\text { associadas à prevalência de IU. }\end{array}$ & Further development of EUI \\
\hline Kocaöz S. & $\begin{array}{l}\text { Age, parity, history of UTI and constipation, } \\
\text { IU in the mother, the sister, IU in a previous } \\
\text { pregnancy and the previous postpartum UI. }\end{array}$ & $\begin{array}{l}\text { Most incontinent women said that UI negatively } \\
\text { impacted their quality of life. }\end{array}$ \\
\hline Adaji S.E. & $\begin{array}{l}\text { Older pregnant women, multiparous, } \\
\text { vaginal delivery, parity, high gestational age. }\end{array}$ & $\begin{array}{l}\text { Most of the women felt that it did not interfere } \\
\text { with daily life, while the rest was interference, } \\
\text { significantly changing their daily routines. }\end{array}$ \\
\hline Sharma J.B. & Age, parity and previous vaginal deliveries. & The hassle of pregnant women and worsening of quality of life. \\
\hline Spellacy E. & Vaginal birth, age, episiotomy, and race. & UI usually affects more than half of women (60\%). \\
\hline
\end{tabular}

Source: Elaborated by the authors.

excess weight that requires continuous effort on the pelvis support agencies are; smoking; constipation; parity (there was no association between UI and type of delivery) [4] [15]-[17] [21]; consumption of two or more cups of coffee a day [27]; perineal trauma in previous birth [22] [23]; loss of urine during pregnancy [15] [17] and ethnicity [4] [23] [25]. The features of lifestyle, sociodemographic, gynecological and obstetric mainly are responsible for influencing the appearance of the UI and the clinical condition that pregnancy provides it make it even more common women file complaints regarding the loss of urine. Pregnant women do not necessarily need 
to have all risk factors for SUI present during pregnancy, just have at least one risk factor or combination between them to cause incontinence [21]. Ideally, the professionals of general practitioners, obstetricians, midwives, nurses, physiotherapists and others who have contact with pregnant women, work aware of the high prevalence of UI in pregnancy, asking when possible on the presence of UI, looking for tender and talk about treatment options, favoring the HP and contributing to their empowerment.

For a higher quality at the incontinent pregnant woman assistance, an interdisciplinary approach is valid, in which information and guidance can be provided [4] relevant by maternal health professionals, in order to develop a holistic and entire care to this woman.

The inclusion of physiotherapists, with urogynecology and obstetrics specialization, at the pre-natal care team is an important step, because they can stimulate and guide the exercises for the pelvic floor [4]. The obstetrician also has an important role at the constant changes that cause urinary dysfunctions, because his/her function may contribute to track and guide pregnant women about the prophylaxis, treatment and impact on daily life [30]. The psychologist can help to ease the impacts on the quality of life of psycho-emotional and social orders, helping the pregnant woman not to isolate from the family and community. The nutritionists can assist in balanced diet, fluid intake and weight control of the pregnant woman.

It is noticeable how these women suffer because they have this problem, apparently harmless, but possessed of emotional and physical exhaustion load that interfere with their daily lives deregulating their desires and emotions. Woman adopts behaviors in an attempt to "circumvent" the symptoms, for exchange and over again of clothes, try to position always close to the bathroom, do not sit, are excluded from society, use liner/diaper to not stay in wet clothes and smelling urine, run to the toilet, seek solitude to protect themselves, they feel fear and shame [31], generating physical and emotional discomfort.

All of these strategies can be a psychological barrier to social interaction. The loss of sphincter control is a fact usually related to children and "in the adult a defect is perceived, so it is not allowed" for these women [31]. Help pregnant women avoid the modifiable factors to reduce the chances of having EUI during pregnancy and postpartum [21] is an action that nurses can develop to contribute to the HP and welfare.

Some factors related to UI in pregnant women can not be changed given the obstetric history, the anatomical and hormonal changes of pregnancy, as well as age and ethnicity. However, other factors such as obesity, high BMI, and smoking, are conditions that nurses can and should be intervening and contributing to the emergence or worsening UI, preventing the increase of its prevalence and reducing the suffering of pregnant women.

Regarding the prevalence of UI in pregnancy, it we found varying rates of $63.8 \%$ in 500 pregnant women with all types of UI [27]; 34\% sample of 294 women [16]; $41.7 \%$ of 722 pregnant women [25] as well as 58.2\%, which is divided into patients with stress urinary incontinence (50.4\%), MUI (28.3\%) and urge incontinence (21.3\%), showing that the pregnancy, this change worsens [28]. The UI was cited by up to $35 \%$ of pregnant women in the previous study [29].

Survey of 620 pregnant women found that in nulliparous, 53.2\% had UI during pregnancy, most of the effort (48.2\%), emergency then (26.1\%) and mixed (25.7\%) and the multiparous group the prevalence was $69.7 \%$, as follows: EUI (54.2\%), MUI (32.8\%) and urgent UI (13\%) [28]. Lowest rates were found in a study of 500 pregnant women, with a prevalence of $7.4 \%$ in pregnant and in women with previous pregnancies was $11.6 \%$ [22].

Research show the appearance of EUI in pregnancy in $57.5 \%$ of episodes, asserting significantly lower incidence of postpartum (13.7\%), suggesting that the process of pregnancy, rather than delivery, is associated EUI [19]. Corroborating this information, the study claims that EUI had a higher prevalence in all trimesters of pregnancy, 37 patients (45.7\%) in the first; 99 (53\%) in the second and 46 (49.5\%) in the subsequent quarter [28] and the EUI, during pregnancy, is the most frequent [16] [20] [21] [25] [28].

There is controversy in the studies when they report that the first quarter is the most common stage appearance [26]; with the largest proportion in the second quarter [26], but they found more literature to affirm that the chance to appear is raised in the third quarter [15] [16] [20] [24] [27].

It is observed that pregnancy, rather than delivery was responsible for triggering the UI. Thus, out of the women with EUI during pregnancy, $56.5 \%$ became asymptomatic. The remission of the symptoms occurred in up to three months after delivery in $87.2 \%$ of cases [19].

It can be highlighted the importance of preventing UI at primary level because it is shown in the prenatal period the first approach of UI prevention among younger women. However, it is known that the appropriate professional assistance focused on pregnant women plays a key role in the holistic perspective on women's health, including prevention of urinary incontinence [27]. 
Have questionnaires that measure the QOL is important for clinical diagnosis and to evaluate the effectiveness of treatments. Thus, they have validated two instruments that detect UI assess the severity and measure their impact on QOL, being validated and suggested by ICS to be used in women as UI measurement questionnaires both in clinical practice as in epidemiological studies and are easily understood by pregnant women [18].

In Brazil, although there are policies related to Women's Health Care, these programs do not include guidelines for care of the pelvic floor and clarification and prevention of urinary symptoms in pregnancy [11].

Ideally, health professionals, especially nurses, obtain the knowledge necessary to understand about UI and to begin to help pregnant women in prenatal consultations, preventing what is possible, supporting them in a meaningful way and seeking health promoting strategies to minimize the social, physical and psychological, resulting from voiding symptoms.

At the nursing appointments, it is indispensable to work the issues in order to diagnose any involuntary urine loss and to add nursing experts at the incontinent population assistance [31]. This revision can help the nurses' knowledge for IU clinical evaluation and QV loss processes, forecasting possible nursing interventions that can ease the generated impacts on the pregnant routine. Besides, the nurse will be able to reflect on proper information transmission and on a good communication with the pregnant, in order to contribute to her empowerment, and, hence, to favor her quality of life.

\section{Final Considerations}

At the found scientific production, it was noticed that the urinary incontinence negatively affects the pregnant' quality of life, their physical, mental, emotional and social domains, leading her to a seclusion from the social relationship and to daily tasks changes, for the generated discomfort and anguish. From this, behavioral strategies will be adapted to this disorder and unconsciously absorbs more worry and anxiety, in addition to those already imposed pregnancy.

It was possible to observe that effort UI (which manifests as physical activity, coughing, laughing or sneezing) is the one that occurs in pregnant women, based on articles found. The woman being older, with the second pregnancy, multiparity, obesity, smoking, BMI, and constipation, are factors presented by pregnant women related to UI. There is no consensus of the authors of the research on the most affected pregnancy period, but the most common were in the third trimester of pregnancy. It is up to health professionals trying to create strategies to minimize the consequences in quality of life generated by the accidental loss of urine. It is suggested a theme deepening searched for the improvement of care for incontinent pregnant to learn effective coping strategies since it is still a small number of articles published on this topic in Brazil and the world.

\section{References}

[1] Abrams, P., Cardozo, L., Fall, M., Griffiths, D., Rosier, P., Ulmsten, U., et al. (2003) The Standardisation of Terminology of Lower Urinary Tract Function: Report from the Standardisation Sub-Committee of the International Continence Society. Urology, 61, 37-49. http://dx.doi.org/10.1016/S0090-4295(02)02243-4

[2] Caetano, A.S., Tavares, M.C.G.C.F. and Lopes, M.H.B.M. (2007) Urinary Incontinence and Physical Activity Practice. Revista Brasileira De Medicina Do Esporte, 13, 245-248.

[3] Robles, J.E. (2006) La incontinencia urinaria. Anales del Sistema Sanitario de Navarra, 29, 219-231.

[4] Oliveira, C., Seleme, M., Cansi, P.F., Consentino, R.F.D.C., Kumakura, F.Y., Moreira, G.A., et al. (2013) Urinary Incontinence in Pregnant Women and Its Relation with Socio-Demographic Variables and Quality of LIFE. Revista da Associação Médica Brasileira, 59, 460-466. http://dx.doi.org/10.1016/s2255-4823(13)70505-8

[5] Barbosa, S.S., Oliveira, L.D.R., Lima, J.L.D.A., Carvalho, G.M. and Lopes, M.H.B.M. (2009) Como profissionais de saúde da rede básica identificam e tratam a incontinência urinária feminina. O Mundo da Saúde, 33, 449-456.

[6] Higa, R. and Lopes, M.H.B.M. (2005) Fatores associados com a incontinência urinária na mulher. Revista Brasileira De Enfermagem, 58, 422-428. http://dx.doi.org/10.1590/s0034-71672005000400008

[7] Minayo, M.C.S., Hartz, Z.M.A. and Buss, P.M. (2000) Qualidade de vida e saúde: Um debate necessário. Ciência \& Saúde Coletiva, 5, 7-18. http://dx.doi.org/10.1590/S1413-81232000000100002

[8] Delarmelindo, R.C.A., Parada, C.M.G.L., Rodrigues, R.A.P. and Bocchi, S.C.M. (2013) Women's Strategies for Coping with Urinary Incontinence. Revista da Escola de Enfermagem da Universidade de São Paulo, 47, 296-303.

[9] Thomason, A.D., Miller, J.M. and DeLancey, J.O. (2007) Urinary Incontinence Symptoms during and after Pregnancy in Continent and Incontinent Primiparas. International Urogynecology Journal, 18, 147-51. 
http://dx.doi.org/10.1007/s00192-006-0124-8

[10] Rezende, J. (2005) Repercussões da gravidez sobre o organismo. In: Obstetrícia, R.J., Ed., 10th Edition, Guanabara Koogan, Rio de Janeiro, 143-73.

[11] Moccellin, A.S., Rett, M.T. and Driusso, P. (2014) Incontinência urinária na gestação: Implicações na qualidade de vida. Revista Brasileira de Saúde Materno Infantil, 14. http://dx.doi.org/10.1590/s1519-38292014000200004

[12] Leroy, L.S. and Lopes, M.H.B.M. (2012) Urinary Incontinence in the Puerperium and Its Impact on the Health-Related Quality of Life. Revista Latino-Americana de Enfermagem, 20, 346-353. http://dx.doi.org/10.1590/S0104-11692012000200018

[13] Dellu, M.C., Zacaro, P.M.D. and Schmitt, A.C.B. (2008) Prevalence of Urinary Symptoms and Associated Obstetric Factors in Adult Women. Revista brasileira de Fisioterapia, 12.

[14] Mendes, K.D.S., Silveira, R.C.C.P. and Galvao, C.M. (2008) Revisão integrativa: Método de pesquisa para a incorporação de evidências na saúde e na enfermagem. Texto \& Contexto Enfermagem, 17, 758-764.

[15] Sacomori, C., Böer, L., Sperandio, F.F. and Cardoso, F.L. (2013) Prevalence of Variables Associated with Urinary Incontinence in the Third Trimester of Pregnancy. Revista Brasileira de Saude Materno Infantil, 13, 215-221. http://dx.doi.org/10.1590/S1519-38292013000300003

[16] Martínez, F.E., Parés, D., Lorente, C.N., Méndez, P.J.R. and Amat, T.L. (2014) Urinary Incontinence during Pregnancy. Is There a Difference between First and Third Trimester? European Journal of Obstetrics Gynecology and Reproductive Biology, 182, 86-90. http://dx.doi.org/10.1016/j.ejogrb.2014.08.035

[17] Kocaöz, S., Talas, M.S. and Atabekoğlu, C.S. (2010) Urinary Incontinence in Pregnant Women and Their Quality of Life. Journal of Clinical Nursing, 19, 3314-3323. http://dx.doi.org/10.1111/j.1365-2702.2010.03421.x

[18] Hernandez, R.V.R., Aznar, T.C. and Aranda, R.E. (2011) Validación de la versión española de las formas cortas del Urogenital Distress Inventory (UDI-6) y del Incontinence Impact Questionnaire (IIQ-7) en mujeres embarazadas. Gaceta Sanitaria, 25, 379-384.

[19] Scarpa, K.P., Herrmann, V., Palma, P.C.R., Ricetto, C.L.Z. and Morais, S. (2008) Sintomas do trato urinário inferior três anos após o parto: estudo prospectivo. Revista Brasileira de Ginecologia e Obstetrícia, 30. http://dx.doi.org/10.1590/s0100-72032008000700006

[20] Adaji, S.E., Shittu, O.S., Bature, S.B., Nasir, S. and Olatunji, O. (2010) Suffering in Silence: Pregnant Women’s Experience of Urinary Incontinence in Zaria, Nigeria. European Journal of Obstetrics Gynecology and Reproductive Biology, 150, 19-23. http://dx.doi.org/10.1016/j.ejogrb.2010.02.008

[21] Sangsawang, B. (2014) Risk Factors for the Development of Stress Urinary Incontinence during Pregnancy in Primigravidae: A Review of the Literature. European Journal of Obstetrics Gynecology and Reproductive Biology, 178, 27-34. http://dx.doi.org/10.1016/j.ejogrb.2014.04.010

[22] Riesco, M.L.G., Fernandes, T.K., Leister, N., Cruz, C.S., Caroci, A.S. and Zanetti, M.R.D. (2014) Urinary Incontinence Related to Perineal Muscle Strength in the First Trimester of Pregnancy: Cross-Sectional Study. Revista da Escola de Enfermagem da Universidade de São Paulo, 48, 32-38.

[23] Spellacy, E. (2001) Urinary Incontinence in Pregnancy and the Puerperium. Journal of Obstetric, Gynecologic, \& Neonatal Nursing, 30, 634-641.

[24] Sharma, J.B., Aggarwal, S., Singhal, S., Kumar, S. and Roy, K.K. (2009) Prevalence of Urinary Incontinence and Other Urological Problems during Pregnancy: A Questionnaire Based Study. Archives of Gynecology and Obstetrics, 279, 845-851. http://dx.doi.org/10.1007/s00404-008-0831-0

[25] Bø, K., Pauck, Ø.G., Sletner, L., Mørkrid, K. and Jenum, A.K. (2012) The Prevalence of Urinary Incontinence in Pregnancy among a Multi-Ethnic Population Resident in Norway. BJOG: An International Journal of Obstetrics \& Gynaecology, 119, 1354-1360. http://dx.doi.org/10.1111/j.1471-0528.2012.03435.x

[26] Sangsawang, B. and Sangsawang, N. (2013) Stress Urinary Incontinence in Pregnant Women: A Review of Prevalence, Pathophysiology, and Treatment. International Urogynecology Journal, 24, 901-12. http://dx.doi.org/10.1007/s00192-013-2061-7

[27] Martins, G., Soler, Z.A., Cordeiro, J.A., Amaro, J.L. and Moore, K.N. (2010) Prevalence and Risk Factors for Urinary Incontinence in Healthy Pregnant Brazilian Women. International Urogynecology Journal, 21, 1271-7. http://dx.doi.org/10.1007/s00192-010-1185-2

[28] Gorbea, C.V., Navarro, S.K., Escobar, B.L. and Rodríguez, C.S. (2011) Prevalencia de incontinencia urinaria en mujeres embarazadas con atención prenatal en el Instituto Nacional de Perinatología Isidro Espinosa de los Reyes. Ginecología y Obstetricia de México, 79, 527-532.

[29] Wijma, J., et al. (2001) Anatomical and Functional Changes in the Lower Urinary Tract during Pregnancy. BJOG, 108, 726-32. http://dx.doi.org/10.1111/j.1471-0528.2001.00123.x 
[30] Moisés, E.C.D., Brito, L.G.O., Duarte, G. and De Freitas, M.M.S. (2011) Disfunções miccionais no período gestacional e puerperal. FEMINA, 39, 409-412.

[31] Higa, R., Rivorêdo, C.R.S.F., Campos, L.K., Lopes, M.H.M. and Turato, E.R. (2010) Vivências de mulheres Brasileiras com continência urinária. Texto \& Contexto Enfermagem, 19, 627-635. 